\title{
Isolation and Characterization of Bacillus
}

amyloliquefaciens TL6 as a Biological Control Agent for Peanut Early Leaf Spot Caused by Passalora arachidicola

\section{Chao Zang}

Liaoning Academy of Agricultural Sciences

\section{Futao An}

Liaoning Academy of Agricultural Sciences

Jinhui Xie

Liaoning Academy of Agricultural Sciences

Ying Lin

Liaoning Academy of Agricultural Sciences

Shuyi Yu

Liaoning Academy of Agricultural Sciences

Xue Pei

Liaoning Academy of Agricultural Sciences

Xiaozhou Liu

Liaoning Academy of Agricultural Sciences

Yuqian Huang

Shenyang Agricultural University

Chunhao Liang ( $\square$ liangchunha099@126.com )

Liaoning Academy of Agricultural Sciences

\section{Research Article}

Keywords: Passalora arachidicola, Bacillus amyloliquefaciens, Peanut, Cercospora arachidicola, TL6, early leaf spot

Posted Date: June 1st, 2021

DOl: https://doi.org/10.21203/rs.3.rs-561390/v1

License: (c) (i) This work is licensed under a Creative Commons Attribution 4.0 International License.

Read Full License 

1 Isolation and Characterization of Bacillus amyloliquefaciens TL6 as a biological

2 control agent for peanut early leaf spot caused by Passalora arachidicola

3 Chaoqun Zang ${ }^{1}$, Futao $\mathrm{An}^{1}$, Jinhui $\mathrm{Xie}^{1}$, Ying $\mathrm{Lin}^{1}$, Shuyi $\mathrm{Yu}^{1}$, Xue $\mathrm{Pei}^{1}$, Xiaozhou

$4 \quad$ Liu $^{1}$, Yuqian Huang ${ }^{2 *}$, Chunhao Liang ${ }^{1 *}$

5 1. Institute of Plant Protection, Liaoning Academy of Agricultural Sciences,

$6 \quad$ Shenyang 110161 , China

7 2. College of Plant Protection, Shenyang Agricultural University, Shenyang,

$8 \quad$ Liaoning, 110866 China

$9 \quad *$ Corresponding Author

10 E-mail: hyqlch@163.com; liangchunhao99@126.com 


\section{Abstract}

Peanut early leaf spot caused by Passalora arachidicola (Cercospora arachidicola), is a worldwide common fungal disease in peanut leaves, which occurs in all production areas in China. To obtain biocontrol resources to control peanut early leaf spot, 60 healthy peanut leaves were collected from major peanut production areas in Liaoning Province. A total of 563 strains were screened from these leaves. Eighteen strains showed differing levels of resistance against $P$. arachidicola. Among these strains, strain TL6 inhibited the pathogen most strongly, and the diameter of inhibition zone was $64.3 \mathrm{~mm}$. This strain was able to inhibit 10 other types of pathogens. It was identified as Bacillus amyloliquefaciens based on its morphological characteristics, physiological and biochemical reactions and a comparative analysis of its $16 \mathrm{~S}$ rDNA sequence. The fermentation liquor of strain TL6 was effective at controlling peanut early leaf spot, and the field control effect was above $69.17 \%$ after spraying the fermentation liquid of TL6. The field control effect was more than $40.96 \%$ after spraying the fermentation liquid diluted 200 times. The field control effect of the TL6 fermentation liquid diluted 200 times and including the addition of $500 \mathrm{~g} \cdot \mathrm{L}^{-1}$ carbendazim diluted 1000 times inhibited $P$. arachidicola by $81.33 \%$. The combination of TL6 and carbendazim had a significant synergistic effect. This strain of B. amyloliquefaciens shows promise for commercial development and application.

Peanut is an important economic and oil $\mathrm{crop}^{1}$. China is the largest peanut producer in the world ${ }^{2}$. The average annual output of peanuts is 17 million $t$ in China, accounting for about $40 \%$ of the world's total peanut output; and the annual export is $700000 \mathrm{t}$, 
accounting for $47 \%$ of the world's total trade in peanuts ${ }^{3}$. Liaoning is a province with large plantings of peanuts. In recent years, the average annual area in Liaoning planted to peanuts has been approximately 370,000 hectares $^{4}$. It has become the third largest cultivated crop after corn and rice. Moreover, peanuts from Liaoning Province are famous in China and throughout the world for their good quality and taste and lack of aflatoxins ${ }^{5}$.

Peanut early leaf spot, caused by $P$ arachidicola $(C$. arachidicola), is a worldwide common fungal disease in peanut leaves, which occurs in all production areas $^{6}$. The disease occurs in the early and middle stage of peanut growth and primarily damages the leaves. When the disease occurs, a large number of round or irregularly shaped lesions appear on the leaves with an obvious yellow halo, causing early defoliation and seriously affecting the photosynthetic efficiency of plants. The yield of damaged peanuts is generally reduced by $15-59 \%$.

Currently, early leaf spot in peanut production is primarily controlled by chemical pesticides $^{8-10}$. However, the problems of resistance, resurgence and residues caused by the long-term use of chemical pesticides have become increasingly prominent ${ }^{11}$. Research on disease management around the world primarily focuses on biological control or the joint management of biological agents and fungicides ${ }^{12}$. During the past few decades, researchers had studied the antagonistic effects of a variety of fungal and bacterial biocontrol agents ${ }^{13-14}$. Bacillus cereus 304 significantly reduced the severity of early leaf spot on chitin-modified leaves ${ }^{15}$. It is clear that research on leaf spot disease caused by $P$. arachidicola is essential for control by plant extracts and 


\begin{tabular}{|c|c|c|c|c|c|}
\hline Strain number & Strain & Inhibition & Strain number & Strain type & Inhibition \\
\hline SY3 & bacterium & $23.7 \pm 1.39 \mathrm{f}$ & DD27 & bacterium & $35.0 \pm 1.48 \mathrm{c}$ \\
\hline SY23 & bacterium & $15.3 \pm 1.08 \mathrm{jk}$ & DD35 & bacterium & $31.3 \pm 0.99 \mathrm{~d}$ \\
\hline FX38 & bacterium & $25.0 \pm 1.61 \mathrm{f}$ & CY5 & bacterium & $15.7 \pm 0.37 \mathrm{ij}$ \\
\hline TL6 & bacterium & $64.3 \pm 1.73 \mathrm{a}$ & CY33 & bacterium & $19.3 \pm 0.83 \mathrm{~g}$ \\
\hline TL22 & bacterium & $33.3 \pm 1.79 \mathrm{~cd}$ & HLD25 & bacterium & $18.0 \pm 0.50 \mathrm{ghi}$ \\
\hline TL35 & bacterium & $18.7 \pm 1.02 \mathrm{gh}$ & HLD41 & actinomycete & $16.5 \pm 1.10 \mathrm{hij}$ \\
\hline LY18 & bacterium & $19.7 \pm 0.70 \mathrm{~g}$ & AS15 & actinomycete & $13.3 \pm 0.57 \mathrm{kl}$ \\
\hline LY55 & bacterium & $10.3 \pm 0.36 \mathrm{~m}$ & AS25 & actinomycete & $17.7 \pm 0.45 \mathrm{ghij}$ \\
\hline DD13 & bacterium & $11.0 \pm 0.45 \mathrm{~lm}$ & TL25 & actinomycete & $25.3 \pm 1.16 \mathrm{f}$ \\
\hline DD14 & bacterium & $12.7 \pm 0.42 \mathrm{l}$ & DD38 & actinomycete & $28.0 \pm 1.36 \mathrm{e}$ \\
\hline DD18 & bacterium & $37.3 \pm 0.79 \mathrm{~b}$ & DD45 & actinomycete & $34.0 \pm 1.70 \mathrm{c}$ \\
\hline
\end{tabular}

biological control instead of using chemicals with the goal of avoiding environmental pollution ${ }^{16}$. We screened microorganisms from peanut leaves to obtain strains with strong inhibitory activity. This research should lay a theoretical foundation for the development of biocontrol agents against peanut early leaf spot.

\section{Results}

\section{Isolation and screening of biocontrol agents against $\boldsymbol{P}$. arachidicola}

A total of 465 microorganisms were isolated from peanut leaves, including 435 strains of bacteria, and 30 strains of actinomycetes. The results showed that 16 bacteria and six actinomycetes showed differing degrees of inhibition against $P$. arachidicola (Table 1). Among them, bacterial strain TL6 showed the strongest inhibitory effect on P. arachidicola, and the diameter of inhibition zone was $64.3 \mathrm{~mm}$ (Figure 1).

Table 1. The inhibitory effect of different isolates against Cercospora. arachidicola Note: Means within the same column followed by different letters (a, b, c, d, e, f, g, h, $\mathrm{i}, \mathrm{j}, \mathrm{k}, 1, \mathrm{~m})$ are significantly different $(\mathrm{P}<0.05)$ according to the Duncan's test. 
the inhibition zone was only $6.2 \mathrm{~mm}$ (Table 2).

A: control; B: treatment with strain TL6

\section{Antimicrobial spectrum assay of strain TL6}

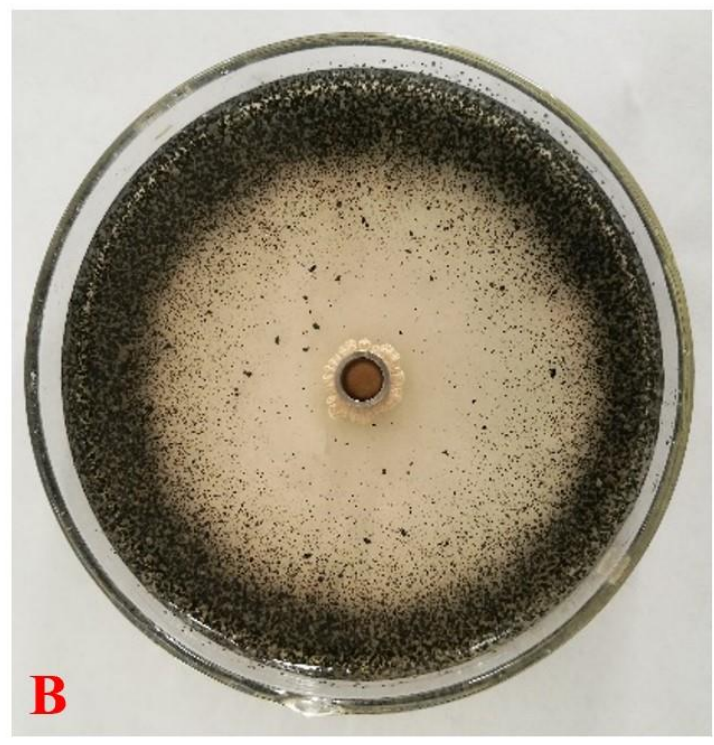

Figure 1. The efficacy of TL6 strain against $C$. arachidicola in PDA plates

Strain TL6 had differing degrees of inhibition on 10 types of plant pathogens, and the inhibitory zones were $6.2-20.3 \mathrm{~mm}$. The inhibitory activity of TL6 strain against $P$. arachidicola was strong, and the inhibition zone was $20.3 \mathrm{~mm}$. However, the inhibitory activity of strain TL6 against Botryosphaeria berengeriana was weak, and

\begin{tabular}{|c|c|c|c|}
\hline Pathogens & $\begin{array}{c}\text { Inhibitory diameter } \\
(\mathbf{m m})\end{array}$ & Pathogens & $\begin{array}{c}\text { Inhibitory diameter } \\
(\mathbf{m m})\end{array}$ \\
\hline $\begin{array}{c}\text { Cercospora } \\
\text { arachidicola }\end{array}$ & $20.3 \pm 0.45 \mathrm{a}$ & Fusarium oxysporum & $13.4 \pm 0.65 \mathrm{c}$ \\
\hline Phytophthora capsici & $16.7 \pm 0.32 \mathrm{~b}$ & $\begin{array}{c}\text { Colletotrichum } \\
\text { orbiculare }\end{array}$ & $12.8 \pm 0.36 \mathrm{c}$ \\
\hline Coniella diplodiella & $8.2 \pm 0.78 \mathrm{f}$ & $\begin{array}{c}\text { Botryosphaeria } \\
\text { berengeriana }\end{array}$ & $6.2 \pm 0.62 \mathrm{~g}$ \\
\hline $\begin{array}{c}\text { Phytophthora } \\
\text { infestans }\end{array}$ & $10.5 \pm 0.43 \mathrm{e}$ & Fusarium graminearum & $9.1 \pm 0.37 \mathrm{f}$ \\
\hline Botrytis cinerea & $11.7 \pm 0.59 \mathrm{~d}$ & Exserohilum turcicum & $15.8 \pm 0.29 \mathrm{~b}$ \\
\hline
\end{tabular}

Table 2. Inhibitory spectrum of strain TL6 against pathogens

Note: Means within the same column followed by different letters (a, b, c, d, e, f) are 
significantly different $(\mathrm{P}<0.05)$ according to the Duncan's test.

\section{Biological control efficiency of strain TL6 strain in the field}

The result showed that the ability of original fermentation solution of TL6 on peanut early leaf spot were $71.34 \%$ and $69.17 \%$ respectively at 2019 and 2020, which was equivalent to the control effect of $500 \mathrm{~g} \cdot \mathrm{L}^{-1}$ carbendazim suspension diluted 1000 times. The control effect of the original fermentation solution of TL6 that was diluted 200 times on peanut early leaf spot were $40.96 \%$ and $42.48 \%$ respectively at 2019 and 2020. The control effect of the TL6 fermentation solution diluted 200 times +500 $\mathrm{g} \cdot \mathrm{L}^{-1}$ carbendazim suspension diluted 1000 times were $84.67 \%$ and $81.33 \%$ respectively at 2019 and 2020, which was significantly higher than that of either treatment used alone (Table 3).

\begin{tabular}{|c|c|c|c|c|}
\hline \multirow{2}{*}{ Treatment } & \multicolumn{2}{|c|}{2019} & \multicolumn{2}{c|}{2020} \\
\cline { 2 - 5 } & Average disease & control effect & Average disease & control effect \\
\hline A1 & 3.61 & $71.34 \pm 2.23 \mathrm{bc}$ & 3.65 & $69.17 \pm 1.93 \mathrm{c}$ \\
\hline A2 & 5.91 & $53.14 \pm 2.14 \mathrm{~d}$ & 5.32 & $55.07 \pm 4.09 \mathrm{~d}$ \\
\hline A3 & 7.02 & $44.35 \pm 2.49 \mathrm{e}$ & 6.67 & $43.67 \pm 2.13 \mathrm{e}$ \\
\hline A4 & 7.44 & $40.96 \pm 1.60 \mathrm{e}$ & 6.81 & $42.48 \pm 0.88 \mathrm{e}$ \\
\hline B & 3.27 & $74.08 \pm 2.68 \mathrm{~b}$ & 3.25 & $72.55 \pm 2.16 \mathrm{bc}$ \\
\hline C & 1.93 & $84.67 \pm 1.39 \mathrm{a}$ & 2.21 & $81.33 \pm 1.41 \mathrm{a}$ \\
\hline D & 12.61 & - & 11.84 & - \\
\hline
\end{tabular}

Table 3. The control effect of stain TL6 against Cercospora arachidicola in the field Note: Means within the same column followed by different letters (a, b, c, d, e) are significantly different $(\mathrm{P}<0.05)$ according to the Duncan's test.

\section{Characterization of strain TL6}

The physiological and biochemical tests showed that the strain TL6 was Gram-positive. It could grow in less than $10 \% \mathrm{NaCl}$ solution and at $5-45^{\circ} \mathrm{C}$. The results of the oxidase reaction, milk hydrolysis, starch hydrolysis, gelatin liquefaction, 
nitrate reduction, citrate utilization, contact enzyme reaction and methyl red test were

101 positive, while the hydrogen sulfide and V-P reaction were negative (Table 4).

\begin{tabular}{|c|c|c|c|}
\hline physiological and biochemical & result & physiological and biochemical & Result \\
\hline Gram staining & + & V-P reaction & - \\
\hline Salt tolerance & $\leq 10 \%$ & Gelatin liquefaction test & + \\
\hline Growth temperature & $5-45^{\circ} \mathrm{C}$ & Nitrate reduction test & + \\
\hline Oxidase test & + & Citrate utilization test & + \\
\hline Milk hydrolysis & + & Contact enzyme reaction & + \\
\hline Hydrogen sulfide generation test & - & Methyl red test & + \\
\hline Starch hydrolysis test & + & & \\
\hline
\end{tabular}

Table 4. The physiological and biochemical characteristics of strain TL6

Note: + indicates a positive reaction. - indicates a negative reaction.

The sequencing results showed that the 16S rDNA of TL6 strain was $1420 \mathrm{bp}$. A

to the type strain of Bacillus amyloliquefaciens ATCC 23350 (Figure 2). Based on its

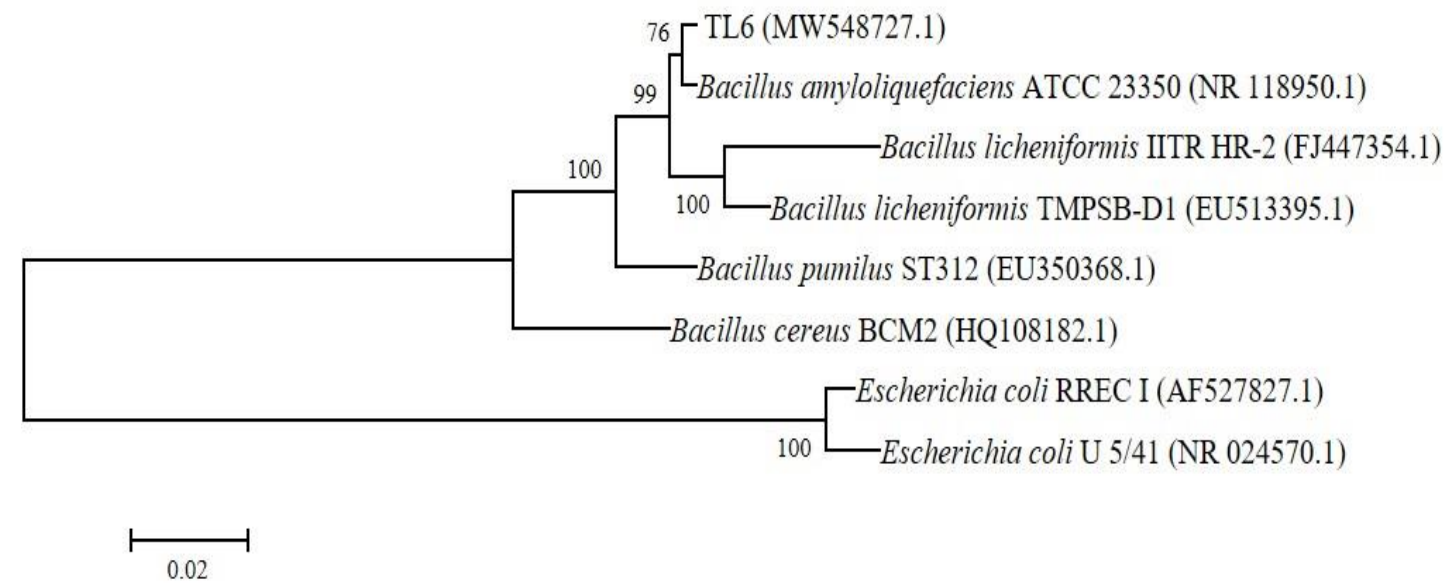

Figure 2. A phylogenetic neighbor-joining tree showing the relationship of the TL6 strain with other related species. Bootstrap values of 100 analyses are shown at the branch points. The scale bar represents two nucleotide substitutions per 100 
nucleotides of $16 \mathrm{~S}$ rDNA sequence.

\section{Discussion}

Early leaf spot is one of the serious diseases that causes substantial economic losses in peanut production. The current control measures primarily rely on the selection of resistant varieties and use of chemical controls. Biological control is considered as one of the most potential control methods for its pollution-free and long-term effects

${ }^{17}$. Extensive research on the development and utilization of Bacillus for biological control have been conducted in China and throughout the world ${ }^{18}$. Currently, there are 110 products registered in China for the control of plant diseases and insect pests (China Pesticide Information Network. http://www.chinapesticide.org.cn/). However, there are no reports on the control of peanut early leaf spot by species of Bacillus. In this study, B. amyloliquefaciens TL6 was screened from peanut leaves, and it strongly inhibited $P$. arachidicola, and it also had different degrees of inhibitory activity against other pathogenic fungi. The control effect of the original fermentation solution of TL6 diluted 200 times against early leaf spot was more than $40.96 \%$. There was no significant difference in the control effect of all the same treatments, which proved that the control effect of TL6 fermentation liquor was relatively stable.

Bacillus amyloliquefaciens was named by Fukomato in 1943 and was not included on the Approved Lists of Bacterial Names and has not been validly published since January $1,1980^{19}$. Bacillus. amyloliquefaciens is found widely in the soil and on plants, fruit and vegetable surfaces, plant compost and healthy animal feces, so it was easy to screen B. amyloliquefaciens with antagonistic activity that 
could not only inhibit the growth of plant pathogens but also promote the growth of crops and improve the number and weight of potential biocontrol agent of fruit ${ }^{20,21} . B$. amyloliquefaciens has a broad spectrum of inhibitory activity that contains rich and diverse active substances, primarily including antagonistic proteins ${ }^{22}$, $\operatorname{surfactin}^{23}$, iturins $^{24}$, and chitinase ${ }^{25}$. These active substances play an important role in inhibiting fungi and bacteria. B. amyloliquefaciens BaX030, isolated from soil, showed strong antagonistic activity against Staphylococcus aureus, Candida albicans, Saccharomycetes, Pyricularia grisea, Colletotrichum acutata and Phytophthora parasitica $^{26}$. Bacillus amyloliquefaciens B190 is effective at controlling lily grey mold (Botrytis elliptica), and the inhibitory effect was even significantly higher than the commonly used fungicides prochloraz and acetamioxime ${ }^{27}$.

As a potential biocontrol microbial resource, B. amyloliquefaciens had not been used to control peanut early leaf spot. In this study, we found that $B$. amyloliquefaciens TL6 was effective at controlling $P$. arachidicola in the field, and combined with carbendazim, it had an obvious synergistic effect. Next, we could explore whether it could colonize the internal parts of peanut plants as an endophyte. On this basis, we separated and purified the antimicrobial active substances of strain TL6 and clarified the antimicrobial mechanisms. This research would provide important security for the development of corresponding biocontrol agents that are safe and effective and could serve as agents for the long-term prevention and control of peanut early leaf spot, and the reduction of chemical pesticides in peanut production. 


\section{Materials and methods}

\section{Sample collection and isolation of bacteria and actinomycetes}

Sixty healthy leaves were collected from Fuxin, Shenyang, Jinzhou, Tieling and other major peanut producing areas in Liaoning Province in China. The leaves were washed with sterile water and cut into 2-3 cm segments, washed with sterile water three times and placed in a beaker. A volume of $200 \mathrm{~mL}$ of normal saline and $0.25 \mathrm{~mL}$ Tween-80 was added, vibrated with $130 \mathrm{r} \cdot \mathrm{min}^{-1}$ at $25^{\circ} \mathrm{C}$ for $30 \mathrm{~min}$ and incubated for $30 \mathrm{~min}$. A volume of $1 \mathrm{~mL}$ of supernatant was smeared on beef extract-peptone agar and Gao's No. 1 media with a coating rod. A single colony was isolated and purified in an incubator at $27^{\circ} \mathrm{C}$ for $48 \mathrm{~h}$.

\section{In vitro evaluation of isolates against $P$. arachidicola}

The effect of the selected bacterial isolates in suppressing the growth of $P$. arachidicola was evaluated using the Oxford cup method in potato dextrose agar (PDA) medium as described by $\mathrm{Chen}^{28}$. A suspension of $1 \times 10^{5}$ spores per milliliter of P. arachidicola was prepared, and $5 \mathrm{~mL}$ of a spore suspension was added to $100 \mathrm{~mL}$ uncoagulated PDA medium, shaken well, and poured as plates. After the media had solidified, the Oxford cup $(\Phi=6 \mathrm{~mm})$ was placed in the center of the PDA plate, and $0.3 \mathrm{~mL}$ of microbial liquid was added to the Oxford cup. The diameter of inhibitory zone around the Oxford cup was measured after incubation for 5-7 days at $27^{\circ} \mathrm{C}$. Each treatment was repeated three times.

\section{Antimicrobial spectrum assay}

Isolate TL6 that had strong inhibitory activity was selected to test against other fungal 
180

181

182

183

184

185

plant pathogens, including Phytophthora capsica, Coniella diplodiella, P. infestans, Botrytis cinerea, Fusarium oxysporum, Colletotrichum orbiculare, Botryosphaeria berengeriana, F. graminearum and Exserohilum turcicum, on PDA plates using the dual culture technique. The pathogen was placed on one side of the plate with culture medium, and TL6 strain was placed on the other side. The addition of just the pathogen to the plates served as the control. The plate was placed in incubators to culture. After incubation for 7 days at $25^{\circ} \mathrm{C}$, the ability of biocontrol agents to inhibit the pathogen was observed ${ }^{29}$.

\section{Biological control efficiency of strain TL6 in the field}

Preparation of original fermentation solution of strain TL6

Preserved strain TL6 was added to the beef extract-peptone media and activated at $28^{\circ} \mathrm{C}$ for $48 \mathrm{~h}$. A $1 \mathrm{~mL}$ suspension of $1 \times 10^{9} \mathrm{CFU} \cdot \mathrm{mL}^{-1}$ of strain TL6 was extracted and added to $110 \mathrm{~mL}$ beef extract-peptone media in a $250 \mathrm{~mL}$ triangular flask and then shaken at $150 \mathrm{r} \cdot \mathrm{min}^{-1}$ at $25^{\circ} \mathrm{C}$ for $96 \mathrm{~h}$ to obtain the original fermentation solution of strain TL6 for following text.

Biological control efficiency of strain TL6 in the field

The experiment was conducted began June 25, 2019 and June 28, 2020 respectively in the peanut experimental plot of Liaoning Academy of Agricultural Sciences, Shenyang, China. Peanuts had been cultivated on this experimental site for many years, and peanut early leaf spot occurred seriously every year. The peanut variety was Silihong. During the experiment, the peanut was only cultivated and managed normally, i.e., it was fertilized and irrigated normally, but no other chemicals were 

17980.85-2004 guidelines (Pesticide--Guidelines for the field efficacy trials (II)--Part

85: Fungicides against Alternaria leaf spots of peanut $)^{30}$, with a total of seven treatments. The treatments included the original fermentation solution of TL6 strain, times (Table 5).

\begin{tabular}{|c|c|c|c|}
\hline Letter & Treatment & Letter & Treatment \\
\hline A1 & $\begin{array}{l}\text { original fermentation solution of } \\
\text { TL6 }\end{array}$ & B & $\begin{array}{c}500 \mathrm{~g} \cdot \mathrm{L}^{-1} \text { Carbendazim suspension diluted } \\
1000 \text { times }\end{array}$ \\
\hline $\mathrm{A} 2$ & $\begin{array}{l}\text { original fermentation solution of } \\
\text { TL6 diluted } 10 \text { times }\end{array}$ & $\mathrm{C}$ & $\begin{array}{l}\text { original fermentation solution of TL6 strain } \\
\text { diluted } 200 \text { times }+500 \mathrm{~g} \cdot \mathrm{L}^{-1} \text { Carbendazim } \\
\text { suspension diluted } 1000 \text { times }\end{array}$ \\
\hline A3 & $\begin{array}{c}\text { original fermentation solution of } \\
\text { TL6 diluted } 100 \text { times }\end{array}$ & $\mathrm{D}$ & control \\
\hline A4 & $\begin{array}{l}\text { original fermentation solution of } \\
\text { TL6 diluted } 200 \text { times }\end{array}$ & & \\
\hline
\end{tabular}

Table 5. The experimental treatment

Each treatment had 30 holes of peanuts. The experimental plots were randomly all levels was recorded as described by Zhou et $\mathrm{al}^{31}$. The leaf grading method was divided into five grades according to the percentage of lesion area in the whole leaf area as follows: grade 0, no lesion; grade 1: the lesion area was less than $10 \%$ of the whole leaf area; grade 2: the lesion area was $10 \%-25 \%$ of the whole leaf area; grade 3: the lesion area was $25 \%-50 \%$ of the whole leaf area Grade 4: the area of diseased leaf 
was $50 \%-75 \%$ of the whole leaf area; grade 5: the area of diseased leaf was more than $75 \%$ of the whole leaf area; the diseased leaves were shed, and the plant died. The control effect was calculated using a disease index.

Where $\mathrm{A}=$ Number of diseased leaves of all levels; $\mathrm{B}=$ the level of each diseased leaf;

$\mathrm{M}=$ total number of leaves; $\mathrm{Bmax}=$ the highest level of disease; $\mathrm{I}=$ control effect;

Zck $=$ the disease index of control group, and $\mathrm{Zx}=$ the disease index of treatment

227 group.

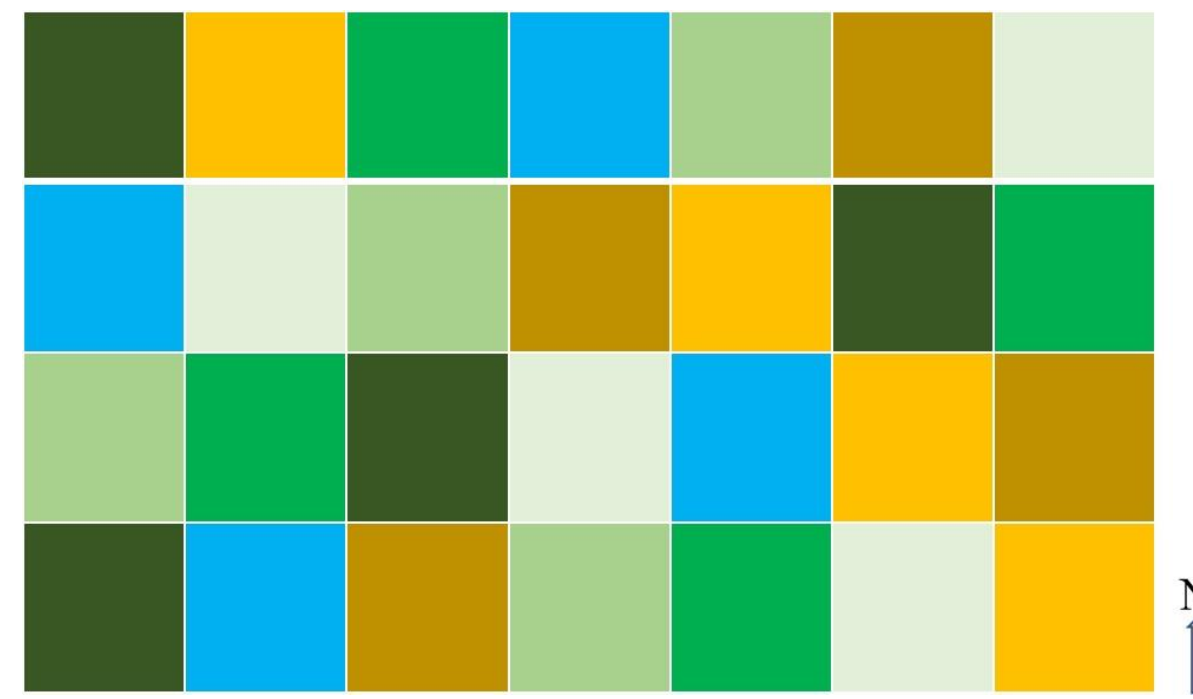

Figure 3. The layout of biological control efficiency in the field assay

A1 represents the original fermentation solution of TL6 strain; A2 is A1 diluted 10x;

A3 is A1 diluted 100x; A4 is A1 diluted 200x; B is in 1000 times of $500 \mathrm{~g} \cdot \mathrm{L}^{-1}$

Carbendazim suspension; $\mathrm{C}$ is $\mathrm{A} 4+\mathrm{B}$; D is the control of clear water.

\section{Characterization of strain TL6}

Physiological and biochemical tests

The physiological and biochemical tests were conducted as described by Dong ${ }^{32}$. The 
following tests were performed on strain TL6: gram stain, salt tolerance test, growth temperature test, oxidase reaction, milk hydrolysis test, hydrogen sulfide test, starch hydrolysis test, and Voges-Proskauer (V-P) reaction among others (Table 4).

\section{$16 S$ rDNA sequence analysis}

To extract the DNA of strain TL6, the cells were harvested from $10 \mathrm{ml}$ of overnight incubated culture, and the pellets were lysed in $1 \mathrm{~mL}$ of lysis buffer ( $25 \%$ sucrose, 20 $\mathrm{mM}$ EDTA, $50 \mathrm{mM}$ Tris- $\mathrm{HCl}$ and $5 \mathrm{mg} \cdot \mathrm{mL}^{-1}$ of lysozyme). The chromosomal DNA was extracted as described by Zhang et $\mathrm{al}^{33}$.

The 16S rDNA was amplified by PCR with the universal primers $27 \mathrm{f}$ (5'-AGAGTTTGATCCTGGCTCAG-3') and $1492 \mathrm{r}$ (5'-GGTTACCTTGTTACGACTT-3'). The PCR reaction system contained $1.0 \mu \mathrm{L}$ DNA, $2.5 \mu \mathrm{L} 10 \times \mathrm{PCR}$ buffer, $0.5 \mu \mathrm{L}$ upstream primer $(27 \mathrm{f}), 0.5 \mu \mathrm{L}$ downstream primer (1492r), $1.0 \mu \mathrm{L}$ dNTP, $0.5 \mu \mathrm{L}$ Taq polymerase, and $19.0 \mu \mathrm{L} \mathrm{ddH}_{2} \mathrm{O}$. The amplification conditions were established for the initial denaturation at $95^{\circ} \mathrm{C}(5 \mathrm{~min})$, followed by 35 cycles at $95^{\circ} \mathrm{C}(30 \mathrm{~s}), 57^{\circ} \mathrm{C}(45 \mathrm{~s})$ and $72^{\circ} \mathrm{C}(1.5 \mathrm{~min})$, with a final extension at $72^{\circ} \mathrm{C}$ for $5 \mathrm{~min}$. The PCR products were sequenced by Shanghai Sangon Biotech, China (https://www.sangon.com/). The sequences were compared using the BLAST program (http://www.ncbi.nlm.nih.gov/BLAST/) to identify strain TL6.

\section{Statistical analysis}

The data were subjected to analysis using one-way analyses of variance (ANOVAs). followed by Duncan's multiple means comparisons at $P<0.05$ (SPSS 24.0, IBM, Inc., Armonk, NY, USA) 


\section{References}

259 1. Pal, K. K., Dey, R. \& Tilak, K. V. B. R. Fungal diseases of groundnut: control and NY. (2014). https://doi.org/10.1007/978-1-4939-1188-2__1.

2. Food and Agricultural Organization of the United Nations (FAO). The state of

3. Du, R. X., Zhang, Y. \& YAO, Y. P. Influencing factors and biological control of aflatoxin contamination in peanuts. Agricultural Biotechnology, 7(2), 22-26 (2018).

4. Yu, S. T., Yu, G. Q., Ren, L., Sun, H. X., Cui, X. Y., You, S. L. Wang, H., Shi, P. X. \& Yu, H. B. The Effect of single-seed precision sowing on peanut yield under different planting density. Liaoning Agricultural Sciences, 6, 19-22 (2018).

5. Zhou, R. J., Xu, Z., Fu, J. F., Cui, J. C., He, J. J. \& Xue, C. Y. Resistance evaluation of peanut varieties to peanut scab and the epidemic dynamics in Liaoning province. Acta Phytophylacica Sinica, 41(5), 597-601 (2014).

6. Yu, S. Y., Zang, C. Q., Xie, J. H., Lin, Y., Pei, X. \& Liang, C. H. Correlation between visible infection rate, airborne conidia density of peanut early leaf spot and meteorological factors. Chinese Journal of Oil Crop Sciences, 41(6), 938-946 (2019).

7. Ghewande, M. P., Desai, S. \& Basu, M. S. Diagnosis and management of major diseases of groundnut. Bulletin, National Research Centre for Groundnut, 
Junagadh, Gujarat, p 36 (2002).

281

282

283

284

285

286

287

288

289

290

291

292

293

294

295

296

297

298

299

300

301

8. Gangopadhyay, S., Bhatia, J. N. \& Godara, S. L. Evaluation of fungicides for the control of collar rot of groundnut. J Mycol Plant Pathol, 26, 278-279 (1996).

9. Nutsugah, S. K., Abudulai, M., Oti-Boateng, C., Brandenburg, R. L. \& Jordan, D.L. Management of leaf spot diseases of peanut with fungicides and local detergents in Ghana. Plant Pathol J., 6(3), 248-253 (2007).

10. Rakholiya, K. B., Jadeja, K. B. \& Parakhia, A. M. Management of collar rot of groundnut through seed treatment. Int J Life Sci Pharm Res., 2(1), 63-66 (2012).

11. Liu, S. H., Ding, Z. P., Zhang, C. W., Yang, B. J. \& Liu, Z. W. Gene knockdown by intro-thoracic injection of double-stranded RNA in the brown planthopper, Nilaparvata lugens. Insect Biochemistry and Molecular Biology, 40(9), 666-671 (2010).

12. Kumhar, D. R., Meena, A. K. \& Meena, P. N. Efficacy of bio agents and fungicides against collar rot and early leaf spot of groundnut. Indian Phytopathology, 71(4), 549-554 (2018).

13. Kishore, G. K., Pande, S. \& Podile, A. R. Biological control of collar rot disease with broad-spectrum antifungal bacteria associated with groundnut. Can J Microbiol, 51(2), 123-132 (2005).

14. Couillerot, O., Prigent-Combaret, C., Caballero-Mellado, J. \& Moenne-Loccoz, Y. Pseudomonas fluorescens and closely-related fluorescent pseudomonads as biocontrol agents of soil-borne phytopathogens. Lett App Microb, 48(5), 505-512 (2008). 
302

303

304

305

306

307

308

309

310

311

312

313

314

315

316

317

318

319

320

321

322

15. Kokalis-Burelle, N., Backman, P. A., Rodriguez-Kabana, R. \& Ploper, L. D. Potential for biocontrol of early leaf spot of peanut using Bacillus cereus and chitin as foliar amendments. Biol. Cont., 2(4), 321-328 (1992).

16. Hasan, M. M., Islam, R., Hossain, I. \& Shirin, K. Biological Control of leaf spot of groundnut. Journal of Bioscience and Agriculture Research, 1(2), 66-78 (2014).

17. Dai, P. B., Lan, X. J., Zhang, W. W., Gan, L., Wang, Y. \& Zong, Z. F. Identification, colonization and disease suppressive effect of strain SC11 against cotton Fusarium wilt. Acta Phytophylacica Sinica, 46(2), 273-279 (2016).

18. Zou, Q. X., Ren, Z. H., Gao, S. H., Zhou, H., Zhao, J. H. \& Liu, E. M. Isolation and Identification of Bacillus subtilis YN145 against Magnaporthe oryzae and Its Antimicrobial Activities. Chinese Journal of Biological Control, 33(3), 421-426 (2017).

19. Priest, F. G., Goodfellow, M., Shute, L. A. \& Berkeley, R. C. W. Bacillus amyloliquefaciens sp. nov., nom. rev. International Journal of Systematic Bacteriology, 37(1), 69-71 (1987).

20. Wang, J. H., Xu, S. Q. \& Zhang, M. Q. Research progress on Bacillus amyloliquefaciens. Subtropical Agriculture Research, 13(3), 191-195 (2017).

21. Almaghrabi, O. A., Massoud, S. I., \& Abdelmoneim, T.S. (2013). Influence of inoculation with plant growth promoting rhizobacteria (PGPR) on tomato plant growth and nematode reproduction under greenhouse conditions. Saudi Journal of Biological Sciences, 20(1), 57-61.

22. Qin, N., Hao, L. \& Li, X. Isolation, purification and inhibitive effect of antifungal 
protein of Bacillus amyloliquefaciens HRH317. Journal of Plant Protection, 42(5), 813-819 (2015).

23. Mikkola, R., Andersson, M. A., Grigoriev, P., Teplova, V. V., Saris, N. E, Rainey, F. A. \& Salkinoja-Salonen, M. S. Bacillus amyloliquefaciens strains isolated from moisture-damaged buildings produced surfactin and a substance toxic to mammalian cells. Archives of Microbiology, 181(4), 314-323 (2004).

24. Hiradate, S., Yoshida, S., Sugie, H. \& Fujii, Y. Mulberry anthracnose antagonists (iturins) produced by Bacillus amyloliquefaciens RC-2. Phytochemistry, 61(6), 693-698 (2002).

25. Yan, X.N., Ma, T.Y., Du, R.J., Jiao, S.Y., Lv, J., Cao, H. \& Han, B. Extracellular antibacterial compounds produced by Bacillus amyloliquefaciens: Research progress. Chinese Journal of Microecology, 30(2), 229-234, 249 (2018).

26. He, H., Zhu, Y. L., Chi, L. Q., Zhao, Z. Z., Wang, T., Zuo, M. X. Zhang, T., Zhou, F. J., Xia, L. Q. \& Ding, X. Z. Screening and antibacterial function of Bacillus amyloliquefaciens BaX030. Acta Microbiologica Sinica, 55(9), 1133-1143 (2015).

27. Chiou, A. L., \& Wu, W. S. (2003). Formulation of Bacillus amyloliquefaciens B190 for control of lily grey mould (Botrytis elliptica). Journal of Phytopathology, 151(1), 13-18.

28. Chen, Z. Y., Liu, Y. Z., Liu, Y. F. \& Xu, P. P. Compatibility between antagonistic bacterial strains and biocontrol efficacy by different bacterial combinations against Fusarium wilt of vegetables. Acta Phytophylacica Sinica, 35(6), 539-544 (2005). 
29. Yoshida, S., Hiradate, S., Tsukamoto, T., Hatakeda, K. \& Shirata, A. Antimicrobial activity of culture filtrate of Bacillus amyloliquefaciens RC-2 isolated from mulberry leaves. Phytopathology, 91(2), 181-187 (2001).

30. GB/T 17980.85-2004. Pesticide--Guidelines for the field efficacy trials( II )--Part 85: Fungicides against alternaria leaf spots of peanut. Beijing: China Stan-dard Press 187-192.

31. Dong, X. Z., Cai, M. Y., Lu, Y.Y ., Xie, J. Y. \& Liu, X. L. Identification methods of common bacteria. Handbook of Common Bacteria Systematic Identify, 349-398 (2001).

32. Zhou, R. J., Xu, Z., Wang, D. Z., Yang, F. Y., Xue, C. Y. \& Fu, J, F. (2014b). Occurrence and epidemic dynamics of early leaf spot of peanut in Liaoning Province. Chinese Journal of Oil Crop Sciences, 36(4), 533-537 (2014).

33. Zhang, M. J., Li, J. L., Shen, A. R., Tan, S. Y., Yan, Z., Yu, Y. T, Xue Z. D., Tan, T. M. \& Zeng, L. B. Isolation and identification of Bacillus amyloliquefaciens IBFCBF-1 with potential for biological control of phytophthora blight and growth promotion of pepper. Journal of Phytopathology, 164(11-12), 11-12 (2016).

\section{Acknowledgements}

We are very grateful to Dr. Tianya Li from the College of Plant Protection, Shenyang Agricultural University for critically reading our manuscript.

\section{Disclosure statement}

No potential conflict of interest was reported by the author(s).

\section{Funding}


369 President of Liaoning Academy of Agricultural Sciences (2020QN2407), Liaoning

370 BaiQianWan Talents Program (2018921035)

$371 \quad$ Statement

372 The peanut or seed/leaf specimens we had been collected was complied with the

373 IUCN Policy Statement on Research Involving Species at Risk of Extinction and the

374 Convention on the Trade in Endangered Species of Wild Fauna and Flora. The

375 Experiments and research conducted on plants or collected plant material are in

376 accordance with Chinese related legislation. 


\section{Figures}
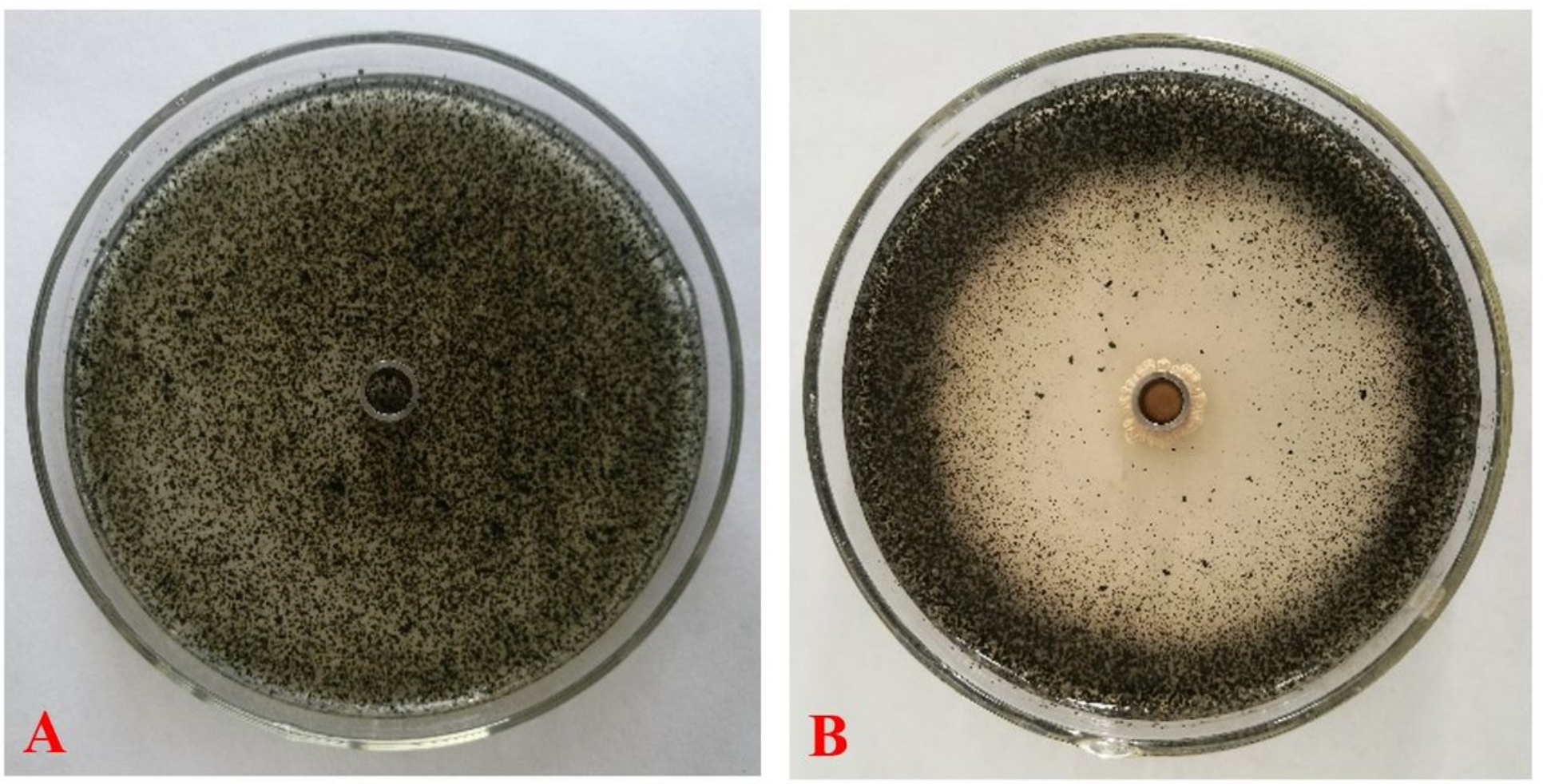

\section{Figure 1}

The efficacy of TL6 strain against C. arachidicola in PDA plates A: control; B: treatment with strain TL6

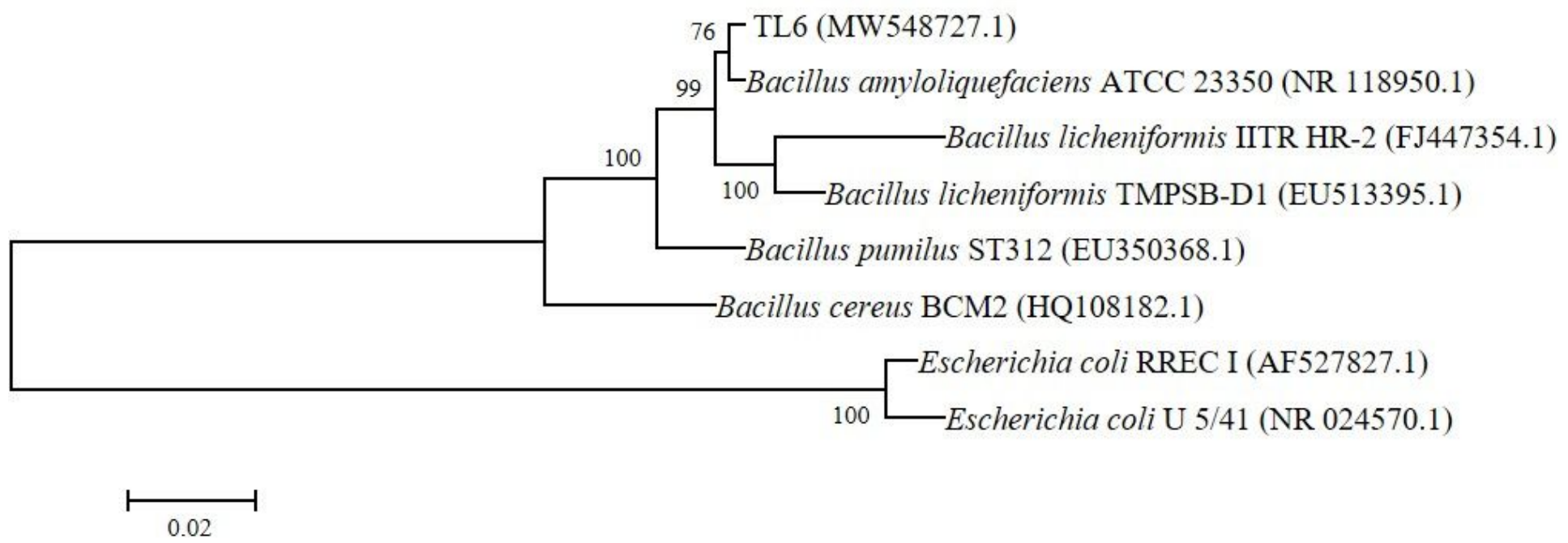

\section{Figure 2}

A phylogenetic neighbor-joining tree showing the relationship of the TL6 strain with other related species. Bootstrap values of 100 analyses are shown at the branch points. The scale bar represents two nucleotide substitutions per 100 nucleotides of $16 \mathrm{~S}$ rDNA sequence. 


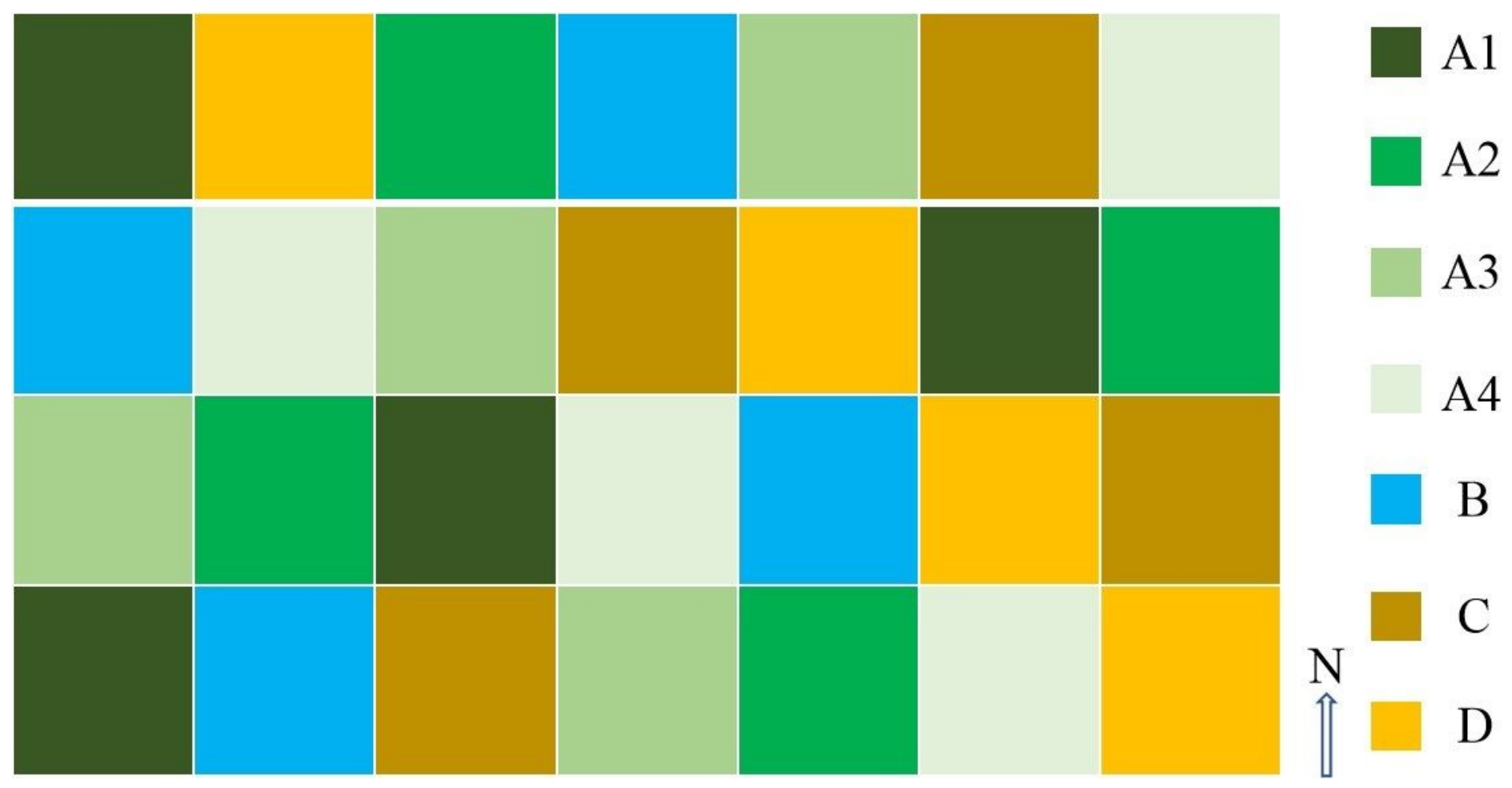

\section{Figure 3}

The layout of biological control efficiency in the field assay $A 1$ represents the original fermentation solution of TL6 strain; A2 is A1 diluted 10x; A3 is A1 diluted 100x; A4 is A1 diluted 200x; B is in 1000 times of $500 \mathrm{~g} \cdot \mathrm{L}-1$ Carbendazim suspension; $C$ is $A 4+B ; D$ is the control of clear water. 